\title{
The Global Public Good and the Opportunity Cost: Is There a Choice for the Marginalised? Hope?
}

\author{
Jamalludin Sulaiman \\ School of Social Sciences, University Sains Malaysia \\ *Corresponding Author: jamals@usm.my
}

\begin{abstract}
Economic growth although well intentioned has both positive and negative impacts. While growth has caused greater inequality, unprecedented poverty and deprivation and many other negative consequences; development can and should reverse this process. The world has plenty. The plague, world wars, HIV/AIDS, tsunamis and epidemics have devastated the human race. But we have bounced back and taken control. The human race is the most resilient and hardy and will overcome challenges and obstacles in many different ways imaginable. Nobody gave up but all bounce back. However, underlying all these assumptions are the opportunity costs to society. It raises the question of global public good. While outcomes of research and development can benefit society, but who should bear their costs? While resources are plenty, should society allow the exploitation of these resources in an unsustainable manner? This paper attempts to present both micro and macro approaches to understanding how society cope under various circumstances form a non-social work perspective. It will justify the use of ex-ante approaches to manage the issues. The impact of HIV/AIDS has gone beyond the health sector. Poverty is just not limited to monetary dimensions but has gone beyond that too. Is there choice for the marginalised? Is there hope for them? While the examples in this paper will refer to issues of HIV/AIDS and the vulnerable poor farmers, other cases will be explored too.
\end{abstract}

Keywords Development, Opportunity Costs, Ex-ante Approaches, Coping Strategies

\section{Introduction}

Economies need to grow because population grows. The world population today is already seven billion and growing, with predictions that it will be 10 billion by 2050 billion and 16 billion by 2100 . Economies must therefore grow to ensure more income and job opportunities to meet the expectation of the growing population and not to mention the need for more food to meet the most basic need. A growing economy provides more job opportunities and thus more income to the families. With more income families are expected to enjoy a better socio-economic wellbeing. This has always been the economic strategy of nations, whether developed or developing, including Malaysia, India, the UK or Australia. However, their respective economic and growth strategies may not be same, but the outcome expected of these strategies has always been a higher national income to ensure, among others, food on the table, employments, education and good health for the growing population.

All countries also have their economic development plans to meet their needs based on availability of their resources. Malaysia's economic growth strategy is guided by its five-year plans since 1956. Malaysia is now under its twelfth plan or the Tenth Malaysia Plan (2011-2015). The first two plans were called the Malaya Plans (First: 1956-1960 and Second: 1961-1965). India's five-year plan started earlier in 1951 and now also under its twelfth plan (2012-2017). There was a break in India's five year plan after the third plan (1961-1966) from 1966-1969 due to many reasons. Indonesia's first five-year plan also started in 1956. Since then Indonesia has also introduced the National Long Term Development Plan (RPJPN 2005-2025) to improve her economy (The World Bank, 2014).

Sen (1999) espoused that development implies freedom. Economic growth must be accompanied by development. Growth and development, although similar, are two very different terminologies to economists. It used to be used interchangeably by many. Their differences, subtle or not, are significant. While growth refers to expanding economic output (an increase of the economic pie); economic development embodies positivity in the concept. It includes equal opportunities and access towards basic human needs, not only in terms of food but also of education, health, employment and economic freedom in terms of gender; and many more. While economic growth is necessary, it is not sufficient without economic development.

For development to happen there must be in place policies concerning food security, environmental sustainability, income and gender equalities and many other social aspects and related policies to ensure inclusiveness of the 
development concept. There must be freedom of choice, not only for those in the upper but also at the bottom of the population. A well designed development policy along with sustainable economic growth agenda is therefore a prerequisite to address social issues to ensure better wellbeing of the population.

The world has plenty to fulfil all the needs; but not all the greed (Mahatma Ghandi). Economic growth, although well intentioned has both positive and negative impacts. Countries in the north are said to enjoy better life, while people of the south struggle to meet their basic needs. While growth has caused greater inequality, unprecedented poverty and deprivation and many other negative consequences, development can and should reverse this process.

The eight Millennium Development Goals (MDGs) are commendable efforts by the world community through the United Nations (UN) to address many of the world's more pressing problems to be achieved by 2015, from halving extreme poverty, stopping the spread of HIV/AIDS, promote gender equality, environmental sustainability, primary education, infant mortality, maternal health and global partnership for development. The UN and its partners are already planning for the post-2015 development agenda for a better world (United Nations, 2014).

This year, 2014, the world celebrated the International Literacy Day on September 8, in Dhaka, Bangladesh. Literacy skill is one of the key elements needed for broader life competencies required for critical thinking, poverty reduction; and sustainable consumption and lifestyles among others, according to the UN.

\section{Social Costs, Choices and Hope}

Cost is a broad concept and may be subjected to various interpretations. The most basic concept of cost is the total value of input used to produce the output using money as the unit of measurement. If the return air fare from Kuala Lumpur to Hyderabad is US\$500, then the cost of the journey is US\$500. Economists view and determine cost differently. The economic concept of cost is less familiar to many. Fundamental in the approach to costs by economists is choices and trade-offs. The underlying economic principle is scarcity as world's resources are limited. A consumer make choices all the time; giving up something for an alternative considered to give more value. The true economic cost is therefore the cost of the next best alternative a person has to give up. This is the concept of opportunity cost (Boardman, Greenberg, Vining \& Weimer, 2011).

Social cost is an even broader concept as this involves consequential cost to society, such as externality issues, which are not usually compensated for. Social cost takes into account everything that may be involved in any activity. Using this concept, the social cost of HIV/AIDS, as an example, is therefore the sum of all costs including what society has to bear directly or indirectly.
Many studies have shown that HIV/AIDS is directly responsible for slowing the economic growth of many countries. The main socio-economic impact is that it decimates the work force and human resources. As AIDS deaths normally occur among workers who are in their most productive years, younger and less experienced workers replace them and thus productivity decreases. The consequential economic impact is growth impaired and development slowed. The impact although small in the beginning, but will over time becomes bigger, if no effective action is taken. Thus, the need for a global support to combat HIV/AIDS is paramount. According to the Millennium Development Goals (MDG) Report 2014 (United Nations, 2014), access to antiretroviral therapy (ART) for control of HIV has increased. In 2012, 9.5 million in developing regions received treatment. ART has saved 6.6 million lives since 1995 according to the report. Economies have a better chance to grow if their workforce is healthy and productive. The social benefit of halting the spread of HIV/AIDS far exceeds the social cost.

The World Health Organisation (WHO) once classified poverty as the world's biggest killer and the greatest cause of ill health. Poverty was given the code Z59.5 under the WHO's Classification of Diseases. Fourteen years ago in 1990 , it was estimated that half the world's population lived on $\$ 1.25$ or less a day. In 2010 , the percentage of the world's population living in extreme poverty dropped to 22 percent. The MDG to half extreme poverty by 2015 is achieved. Reducing extreme poverty helps solve many other associated ills such as mental illness, suicides, family disintegration and substance abuse, which indirectly increases the nation's productivity and economic growth. However, extreme poverty is still a major concern as 1.2 billion in 2010 of the world's population are still suffering. A third of that lives in India, 13 percent in China, nine percent in Nigeria followed by Bangladesh and Republic Democratic of the Congo at five percent each. The MDG has given the poor hope.

Other disease epidemics and natural disasters can cause similar economic damage to an economy. Foot and mouth disease (FMD) outbreak in the United Kingdom not only severely reduced the agricultural sector's revenue; it actually had a greater impact on tourism revenue (Blake et al, 2001). Malaysia experienced a severe haze problem in 1997, which devastated the fishing industry and led to a loss of productivity to many other economic sectors including aviation industry due to flight delays and cancellations, and the tourism industry. It was reported that environmental sustainability efforts has not been quite successful with $\mathrm{CO}_{2}$ emission still increasing and millions of hectares of forest cut down every year to be planted with more profitable cash crops. Malaysia and the region continue to have the haze problems, an externality brought about by forest cutting in neighbouring countries.

When resources are limited, choices have to be made. When providing a public good, like education and health, the state must ensure that the policy can benefit society. To 
provide better education and health services, for example, something else has to be given up. To the individual, pursuing higher education entails additional costs for tuition fees, books and other related expenses. But the opportunity cost of education also includes the three to four years of forgone income as in salary or wages while attending college. The cost to the nation, which includes the infrastructure cost and salaries and wages, is definitely huge. Governments forgo other development projects, the opportunity cost of education, to finance university education. As a footnote, few countries prefer military spending over spending on social services like health and education.

Thus, economies make choices to plan for development given the limited national resources. Families make choices and often time sacrifices to ensure their wellbeing and for a better future of the younger ones, limited only by their wealth and income. Individuals make choices in their daily lives to get through the day, given the limited time.

An economist looks at a problem as an issue of choice and making economic decisions to maximise ones utility or benefit. Whether consciously or unconsciously, everyone has to make choices; and perhaps do it all the time, given the alternatives and within the scope of the choice set. With more wealth and resources, the scope for development is bigger. When resources are limited, the alternatives available are limited, thus a smaller choice than that of an individual with relatively more wealth and resources.

\section{Do the Marginalised have a Choice? Do They have Hope?}

As an economist, the most immediate or spontaneous reaction to the question is yes, as everyone has a choice, including the bottom billion and the marginalised. Life, as some put it, is a never ending sequence of making decision on every aspect of our daily lives. Some decisions are simple and others may be fairly complex choices that one has to make. Nevertheless, a choice has to be made between alternatives, including doing nothing about a situation.

Scientists, including economists are still experimenting on how people make decisions under different circumstances and have proposed several views. An economic view is when a person, given limited resources, makes a decision using economic rationale to purchase a given good or service. A passive view is just the opposite. People are assumed to be submissive and readily accept what is available or offered and often hyped. Similar to economic rationale, some decisions are made to solve a given problem and the associated risks, which people such as farmers often face. A decision is only made once sufficient information is available. This is the cognitive approach. Some people decide on impulse to make themselves feel emotionally better (such as to look better or be sexier, to forget about problems or to have more fun), this is the emotional approach to decision making.

The above views notwithstanding to the discussion, choices are made given the alternatives or resources available. Of the surface of the planet earth, slightly less than 30 percent is land and only about half of land is arable and useful for habitation. The majority of the world's population has little or no access to these resources for many different reasons, including structural, political, in fact many more. The world's richest 20 percent consume 76.6 percent of total output; world's middle 60 percent consume 21.9 percent; thus leaving only 1.5 percent of total output to be consumed by world's bottom 20 percent in the hierarchy, or the poor. For every dollar the rich consume, the bottom 20 percent, the poor, have at their disposal about two cents worth of consumption. And, a great majority of them are in Asia and with even greater proportion of them in South Asia.

Do the marginalised have hope? It is no longer a question as without hope, there is little for the future of the marginalised. Hope is positive outcome desired of one's life and circumstances. Almost everything is possible with hope. Hope can be reinforced with some social support system. All over the world, in rich and poor countries, there are "socioeconomic safety nets" or "social safety nets" programs to help the poor and vulnerable from external shocks and poverty. Cash transfers; food based programs such as food stamps (USA), soup kitchens and the vulnerable group development program (VGD) in Bangladesh; price subsidies (including in Malaysia); fee waivers in public schools and hospitals and many more. Public works program provide the unskilled workers temporary jobs in critical times such as building or improving basic infrastructures (roads and bridges). The outputs of public programs are job creations and more.

An economy or a nation in the quest for better economic growth and aiming to overcome unavoidable structural or market problems provides selected goods and services in the form of public goods. A public good is an item of consumption not decided by the individual, but by society and is financed by the state or the taxpayers. It is a good when consumed will not reduce its availability to others and no one can be excluded from consuming it. It is produced because its overall social benefits are greater than its social costs. In economics term, it is non-rivalrous and non-excludable and the degree of 'rivalrous-ness' and 'excludable-ness' of the public good determines its 'pure-ness'. This paper will not dwell into it, but for the purpose of this paper, a public good is used in its broadest term. It is any good that is made available to the public for free. Frequently used example of a public good is national defence to protect the nation's sovereignty. Other examples include free education and health care, basic television and radio broadcast services; and environmental sustainability programs. A 'social safety net' program is a form of a public good.

\section{Global Public Good}

Global public good is a relatively recent concept. Public 
goods become global when the benefits of a public good benefits multiple groups and populations including those beyond the national boundaries. MDGs efforts are a form of global public good. It's a shared responsibility by the global community for the benefit of the underprivileged, marginalised and those who unfortunately lack the resources. It is also a form of ex-ante approach to preventing bigger future national and international problems. The cost is shared by all based on their ability to contribute to the fund. A global public good in its broadest term also include sharing of critical resources to prevent even a bigger international disaster. Prevention of spread of diseases, care of the environment, sustaining and prevention of resource exploitation are some reasons for the need of a global public good. The concept of public good should also include critical resources with consumption available to all without exclusion and rivalry. These are again ex-ante approaches for the wellbeing of the current and future generations.

Globalisation brings about benefits and new challenges. With faster air travel, nations are but just hours away from one another. A well-developed economy is only hours away from the poorest countries in the world. So can diseases travel as fast and if not contained immediately can be devastating to the international community.

\section{Discussion and Summary}

The above discussions appear piecemeal. The purpose is to introduce and discuss some related and common economic concepts and to propose how these concepts may be tied together to form a coherent discussion related to theme of the conference. The world has plenty to fulfil all the needs of today but with growing population, providing for the future is a greater challenge. Resources are not evenly distributed and few countries are more prone than other countries to natural disasters and calamities. Consumption around the world is uneven with the world's richest 20 percent consuming 76.6 percent of total output. The bottom 20 percent consumes only 1.5 percent of total output.

While public goods addresses market distortions and failures in an economy, global public goods have potential to mitigate even bigger world's distortions and inequalities. The environment, especially its biodiversity; the food chain, including resources of the sea; and disease epidemics, all have the potential to create a huge impact on the future survival of the human race if not managed or tackled effectively. The new buzz word is 'green', just like previous buzz word, 'globalisation' of the mid-1980s. It is all about sustainability for the future generations. 'Green economics' proposes changes in the current economic models to benefit the widest number of people possible and sustainability of our resources. These are actually the fundamental aims of global public goods - for the benefit of the global community, while 'sharing' available sources. It is green for addressing the problems, not only of the environment, but also of the social issues. This new development platform is for all - engineers, economists, banker and the helping professionals, including the social workers.

This author is an economist by training, who wishes to claim to know a little about social work, one of the most misunderstood helping professions in Malaysia and the world. Economists talks about choices given the limited resources. Research and development (R\&D) requires resources. Private enterprises need to remain afloat to continue with their R\&D efforts. The poor cannot afford the expensive vaccines and drugs for prevention and treatment of diseases. If with international support, the vaccines and drugs can be made available to the less fortunate population, their wellbeing can be ensured. Thus the need for global public good to be further debated, expanded and accepted. Support from the state can be assumed as given. Only how much is the question, which essentially falls back to the question how much are the available resources and what are the priorities.

The global community is not insensitive to world's problems and challenges. The United Nations through its many bodies including United Nation Children's Fund (UNICEF), United Nations Development Programme (UNDP), World Food Programme (WFP), Food and Agriculture Organization of the United Nations (FAO), United Nations Population Fund (UNFPA), United Nations Relief and Work Agency for Palestinians in the Near East (UNRWA) and its specialised agency such as International Fund for Agricultural Development (IFAD), has many programmes to address almost every aspect of the world's immediate and serious issues. Other specific efforts include the RIO 21 agenda for sustainable development and the World Trade Organisation (WTO) to encourage free trade. The Asian Development Bank (ADB) and the Islamic Development Bank (IDB) and the World Bank have similar development agendas.

The eight Millennium Development Goals (MDGs) of the $\mathrm{UN}$ is nearing the target date to realise its aim by 2015. Many of the MDGs have been met including halving extreme poverty, fight against tuberculosis and malaria showing positive results and gender disparity in schools is minimised. In other aspects, the MDGs have shown substantial progress as in the control of HIV/AIDS epidemic, although containing $\mathrm{CO}_{2}$ emissions to prevent global warming needs more international cooperation and efforts. There are already plans for the post-2015 development agenda for a better world.

What else can nations do to realise their development agenda? What can be done given the limited resources of some nations? China is a new super economic power and now producing almost everything for the global market. India's middle-income class is growing due its huge human capital. Vietnam, following China's model, is also a now emerging economy with great potential. Myanmar's economy is set to grow since being taken over by the civilian government in 2011. The Asian Development Bank has undertaken to finance Myanmar's infrastructure development. Indonesia, once a chronic dropout economy as described by some, is already self-sufficient in rice to feed 
her 250 million people. The most populous country in Southeast Asia and the fourth biggest in the world, Indonesia have great potential if their human capital continues to be developed. The World Bank rescued Indonesia's economy in 1998 due to the Asian Financial Crisis. Underlying the development of all these nations are proper economic planning and international support for those countries with less resources.

The poor and the marginalised will have choices when given the right support. Support from within and outside are there to be explored. With support from the state, the poor and the marginalised can have hope. With freedom and opportunities, the poor and the marginalised can have better prospects to escape the vicious poverty cycle.

\section{REFERENCES}

Blake, A. (2003). Quantifying the impact of foot and mouth disease on tourism and the UK economy.
Tourism Economics. 11/2003: 9(4): 449-465. doi: 10.5367000000003322663221

Boardman, A. E., Greenberg, D. H., Vining, A. R. \& Weimer, D. L. (2011). Cost-benefit analysis: Concepts and practice $\left(4^{\text {th }} \mathrm{ed}\right.$.). New York: Pearson.

Othman, M. S. \& Othman, J. (1999). Malaysia. In Glover, D. \& Jessup, T (Eds). Indonesia's fire and haze: The cost of catastrophe (pages 22-50). Singapore: Institute of Southeast Asian Studies.

Sulaiman, J. \& Azman, A. (2010). The economic cost of HIV/AIDS and the policy implications. In

Azman. A, Baba. I, Sulaiman, J. \& Paramaswari, J. (Eds). HIV/AIDS prevention, treatment and care: The way forward. Penang, Malaysia: AIDS Action \& Research Group, Universiti Sains Malaysia.

Sen, A. (1999). Development as freedom. London: Oxford University Press.

The World Bank (2014). Indonesia: Overview. Retrieved from http://www.worldbank.org/en/country/indonesia

United Nations. (2014). The millennium development goals report, 2014. New York: United Nations 